\title{
Caring and Role Modelling the Essence of Nursing
}

\author{
Shirin Badruddin* \\ Aga Khan University School of Nursing and Midwifery, King Faisal Specialist Hospital and Research Center, Saudi Arabia
}

Submission: December 12, 2018; Published: March 22, 2018

*Corresponding author: Shirin Badruddin, Clinical Specialist, King Faisal Specialist Hospital and Research Center, Saudi Arabia, Tel: 966551250796; Email: shirin_badruddin@msn.com

\begin{abstract}
Caring is identified as an integral part of nursing practice and education. Care is the essence and central significance of nursing profession. The care has been postulated to be an essential human need for the full development, health maintenance and survival of human beings Leningrad [1]. It is evident that caring has broad term and it reflects person's attitude and behavior towards patient. Role modeling plays a very important role and it is very important how faculty carry themselves on clinical. Students copy the same behavior which faculty actually performs. Role modeling influenced a lot on clinical learning environment and on the development of competence. Clunking, Sawasdisingha, Viseskul, Funashima, Kameoka, Nomoto \& Nakayama.
\end{abstract}

\section{Introduction}

Now, it is time to reflect what will be the nursing profession without caring. This paper will examine how caring can be integrated in to nursing education. It is also important to understand the caring roots of our profession. This paper will discuss conceptual framework and, strategies to improve role modeling. Watson believes that caring and love are included in the practice of nursing and reaches the highest level Wagner \& Whaite et al. The word nurse is an ancient word derived from old French (nurrice), and Latin (nutricius). All of these terms are associated with the ideas of nourishing, fostering, caring, and providing curative care Leninger [2] Wagner \& Whaite.

\section{Historical Glance of Caring in Nursing Profession}

In the Islamic context, concept of caring is rooted and has been part of nursing since the time of Rufayda Al-Islamiyah and at that time she used to take care of patients. The phenomenon of caring in nursing has been further displayed by Florence Nightingale Wagner \& Whaite. The concept of care wasn't explicitly defined by Nightingale; however, one would infer aspects of care from her writing about patient's condition and the nurse's attitudes and actions Leninger [2]. Her work in the Crimean war demonstrated the importance of nursing care in saving lives. At that time, nursing was getting education from medical personnel. Nightingale advocated establishing nursing school but nursing was still sharing authority with medical personnel. After strong hardship, nursing caring model is separated from medical model around 1970 Bevis \& Watson [3]. King, Peplau, Leninger and Watson shifted their focus towards nursing model. Leninger, Peplau and Kolcaba stimulate nurses to study care and laid the foundation of human caring in nursing. In 1985 Watson describes transpersonal caring in nursing and lists 10 carative factors that nurse should use in their roles which are as follows:

a. Formation of humanistic altruistic system of values

b. Instillation of hope/ faith

c. Cultivation sensitivity to self and others

d. Development of a helping, trusting, human care relationship

e. Promotion and acceptance of the expression of positive and negative feelings

f. Systematic use of a creative problem solving process

g. Promotion of transpersonal teaching/ learning

h. Provision for supportive, protective and or corrective, mental, physical, societal and spiritual environment.

i. Assistance with gratification of human needs

j. Allowance for existential phenomenological spiritual forces

It is right to say that Watson's transpersonal caring lays the foundation of science and humanistic approach of caring in nursing. Watson curative factors can be easily applied to nursing curriculum and should be implemented by an educator.

\section{Caring in Nursing Education}

Nursing education is an important aspect in restoring caring to the nursing practice. Caring in nursing education is expressed through interactions between the faculty and nursing students. 
In other words, teacher and students are like partner in students learning process. Nursing text books have also stressed that attributes of nurse should be those of dedication, kindness, compassion, patience, trust worthiness, self-control, discretion, humility and respect Bradshaw [4]. Professional nursing behaviors are highly dependent on teaching and learning transactions that occur in the academic setting which are eventually transferred and honored in clinical practice environments. Caring in nursing education is multidimensional concept expressed through interactions among the nursing faculty, between the faculty and nursing students Chinn \& Watson [5]. Nursing students are required to develop attitudes, beliefs and values that are central to nurturing and caring perspective of nursing Brown [6]. Nursing education integrates three domains of learning such as cognitive, psychomotor and affective to enhance the graduate's knowledge and skills for competent practice and attitudes that promote humanistic caring with patients Brown [6]. Many nursing curriculum include teaching and learning strategies that support critical reflection and gradual identification of caring. Role playing, reflection papers, case studies, clinical simulations have the potential for maintaining the focus on caring Brown [6].

\section{Combination of Art and Science in Nursing}

The researchers believe that art of nursing and science of nursing are mutually important to nursing practice and embrace the importance of a caring relationship in all nursing relationships Waigner \& Whaite. Leninger has emphasized both humanistic and scientific approach in nursing education Chinn \& Watson [5]. In relation to this context, previously people from science and arts background were given admissions in nursing. Currently, the students from science background are giving permission to acquire nursing education. Some people view that students from arts have humanistic approach and are better able to provide caring attitude as compared to students from science background. Others have opinion that caring starts from home and we learn caring, respect and basic values from home or society before entering into nursing profession. Some have assumptions that caring is changing. Previously, mothers were taking care of their children and now they are giving their children to baby sitters. In this way, nurses caring will not be same for the patient and will see a change. I think it is a biggest challenge for nurse educators how to instill caring attitude among student or teach them caring behavior. With this changing world, whether we should change our caring. I have learnt that caring is caring and is innate. Form of caring can be changed but the essence of caring can't be changed.

Conceptual Framework: Quality-Caring Model for Educational Program Evaluation

The quality caring model for educational program evaluation is proposed by Duffy and Hoskins in 2003. This model is dynamic and evidence based. In this model, the structure component includes characteristics of faculty, students and the educational system. Concepts and sub concepts included in this component may directly or indirectly influence educational outcomes. The process component includes the two essential caring relationships that comprise the work of nursing faculty. The independent relationship between students and faculty members carry out in partnership with students during the learning process. The third major component of the model outcomes shows the end result of the educational process. Two forms of outcomes are obvious. Intermediate outcomes represent a change in student's behaviors, emotions or knowledge while terminal outcomes are those major end result concepts that affect the future of a program such as satisfaction, personal growth, specific student learning outcomes and resource use are examples. The major proposition of the model is that relationships characterized by caring among teachers and students contribute to positive educational outcomes. Moreover, the structure-process-outcomes components are a function of time and circumstance and are not simply a linear chain of events Duffy \& Hoskins [7].

\section{A New Approach to Teaching Caring in Nursing}

Nursing education needs to do more than provide students with the knowledge and skills. It should provide students with the self-confidence necessary to challenge the existing system and to practice nursing from a caring perspective Bevis and Watson [3]. Bevis and Watson further stressed that connectedness are essential to human problem solving and the discovery of knowledge. It is important to identify the definition of teacher student relationship in nursing education. The nature of caring relationship is consistent and the roles are determined. In caring curriculum, knowledge of particular subject is taught and students are given more importance than the knowledge. Students are not punished if they failed to receive grades according to standards. They are facilitated to reevaluate themselves and assist in selecting realistic educational objectives Nodding [8]. Identifies four teaching elements: modeling, dialogue, practice and confirmation that facilitate the development of a caring and can be used among students.

\section{Role Modeling}

Caring is modeled by the manner in which teachers respond and encourage questions, resolve queries and evaluate student performance. Modeling provides students with the experiences of being cared for. Students also observe caring being modeled when the teacher interacts with other students or teachers Noddings [8].

\section{Dialogue}

A caring curriculum works toward establishing genuine dialogue between teachers and students. By participating in a genuine dialogue with teachers, students learn how to express their ideas and integrate theory and knowledge. In this way, students develop self-confidence and learn to present an argument to respect the opinion of others and interact more effectively Noddings [8]. 


\section{Practice}

Noddings [8] mentioned that caring begins in the classroom. Nursing education includes practice in clinical settings where students, under the guidance of their instructor assume the role of nurse and this is very important element of teaching. Teacher should be very careful while practicing this mode of teaching because student may learn some negative thing during their practice. Students may observe some negative clinical practices on clinical and is the role of teacher how she teaches students from negative observations and that help to bring caring attitude among students.

\section{Conformation}

The question that arises in this phase is how does one confirm the best in student when the student is unable to pass the course? This means confirmation talks about evaluating. Students have to achieve an acceptable level of knowledge and performance in order to progress. As a clinical personnel, patient safety is the highest priority and we are in dilemma whether to support that student or not if student is not performing according to the standards. However, Nodding [8] Stated that when a caring teacher-student relationship has developed, students are better able to look at the reasons of their clinical failure and establish realistic educational goals for their future. In this way, students learn more and better able to provide caring attitude to patient. This element is very important because teacher may become emotional and don't think about the patient safety. Teacher should work in partnership with student and help them to overcome his failures.

\section{Recommendation}

Caring relationship should be part of nursing school philosophy and curriculum development. Caring should be incorporated into the curriculum through the establishment of a learning environment that promotes caring relationship between teacher and student, student and student and among faculties [9]. It is important for educators and practicing nurses to present, role model the actions and attitudes of a caring relationship to their students Wagner \& Whaite. Educational institutions and nurse educators have the responsibility to prepare new graduates with the competencies necessary to provide safe, competent and ethical nursing care. Excellent teachers are described as possessing sound knowledge of their own discipline and knowing how to motivate students (Sawatzky, Enns, Terrij, Davis and Harder) [10]. Nurse teacher should continuously develop their behavior in relation to respect for students, showing the value of nursing practice and the nursing profession in order to being a good role model in nursing Klunklin.

Faculty should use teaching style that helps to promote caring attitude among students. It is suggested that evaluation of caring behavior should be done as formative clinical evaluation process and should be given some grading on the basis of rubric. Caring should be evaluated during skills lab or throughout program in form of formative or summative evaluation and nursing text books should be reviewed. Nurse educator should also see how well the art fits in the university philosophy and mission. Nurse educator should take serious steps regarding recruiting students for nursing education in school and we should tell the actual picture of nursing and caring for patient. People from different backgrounds should be selected on merit basis and we should use proper interview techniques to assess student caring and level of thinking about nursing profession.

\section{Conclusion}

Teacher and nursing student has a mutual relationship in learning cycle. Nursing students learn from their faculties and faculties should demonstrate caring attitude in front of students. The outcome of nursing education is that nursing student demonstrate caring attitude towards patient and work for patients benefit by counseling and advocating [11]. There are several forces acting on the curriculum and nursing educator has to work in coordination with them. This means curriculum revolves around institution, home and society. Teacher should facilitate and role model by using several strategies in class room and clinical settings to develop caring insight among students. Kolcaba and Watson can be easily applied by nurse educator in classroom. Kings and Peplau theory lay the foundation for interaction and that helps to achieve the caring attitude among students [12]. It is right to say that we should incorporate nursing theories in our nursing curriculum because theories lay the true foundation of nursing and should be taught to students. The article can be concluded with the Leningers [2]. definition of nursing: The real essence of nursing, as of any fine art, lies not in the mechanical details of execution, nor yet in the dexterity of performer, but in the creative imagination, the sensitive spirit and intelligent understanding lying back of these techniques and skills. Without these [13]. Nursing may become a highly skilled trader, but it cannot be a profession or fine art.

\section{References}

1. Leninger MM (1988) Care the essence of nursing and health. Wayne State University Press, Detroit, Michigan, US.

2. Leninger MM (1988) Care Discovery and uses in clinical and community nursing: Wayne State University Press, Detroit, Michigan, US.

3. Bevis E0, Watson J (1989) Toward a caring curriculum: A new pedagogy for nursing. National League for Nursing 15(2278): 1-394.

4. Bradshaw A (1998) Charting some challenges in the art and science of nursing. The Lancet 351: 438-440.

5. Chinn PL, Watson J (1994) Arts and aesthetics in nursing. National League for Nursing Press, New York, USA.

6. Brown LP (2011) Revisiting our roots: Caring in nursing curriculum design. Nursing Education in Practice 11(6): 360-364.

7. Duffy JR (2011) Want to graduate nurses who care? Assessing nursing students' caring competencies.

8. Noddings $N$ (1988) An ethic of caring and its implication for instructional arrangements. American Journal of Education 96(2): 177-230. 
9. Duffy JR, Hoskins LM (2003) The Quality-Caring model: Blending dual paradigms. Advances in Nursing Science 26(1): 77-88.

10. Goodwin M, Sener I, Steiner SH (2007) A novel theory for nursing education. Holistic comfort. Journal of Holistic Nursing 25(4): 278285.

This work is licensed under Creative Commons Attribution 4.0 License DOI: 10.19080/JOJNHC.2018.07.555701
11. Ramey Sl, Bunkers SS (2006) Teaching the Abyss: Living the art science of nursing. Nursing Science Quarterly 19(4): 311-315.

12. Watson J (1985) Nursing: Human science and human care. Appleton Century Crofts, Norwalk, CT, US.

13. (2010) Pakistan faces shortage of nursing service.

\section{Your next submission with Juniper Publishers will reach you the below assets}

- Quality Editorial service

- Swift Peer Review

- Reprints availability

- E-prints Service

- Manuscript Podcast for convenient understanding

- Global attainment for your research

- Manuscript accessibility in different formats

( Pdf, E-pub, Full Text, Audio)

- Unceasing customer service

Track the below URL for one-step submission https://juniperpublishers.com/online-submission.php 